\title{
Segregation and Linkage of Several Genes in Cucumber
}

\author{
S. Alan Walters ${ }^{1}$ \\ Department of Plant, Soil, and General Agriculture, Southern Illinois University, Carbondale, IL 62901-4415 \\ Nischit V. Shetty ${ }^{2}$ \\ Seminis Vegetable Seeds, 432 TyTy Omega Road, Tifton, GA 31794 \\ Todd C. Wehner ${ }^{3}$ \\ Department of Horticultural Science, North Carolina State University, Raleigh, NC 27695-7609
}

AdDitional INDEX words. Cucumis sativus, vegetable breeding, disease resistance, gene mutants

\begin{abstract}
Gene linkage was investigated in 11 families using 18 genes in cucumber (Cucumis sativus $\mathrm{L}$.). The genes studied were $B$ (black spine), $B-3$ (Black spine-3), B-4 (Black spine-4), bi (bitterfree cotyledons), Bt (bitter fruit), Bt-2 (bitter fruit2), $D$ (dull fruit skin), $d f$ (delayed flowering), $d e$ (determinate habit), $F$ (female sex expression), $g l$ (glabrous foliage), $l h$ (long hypocotyl), $n s$ (numerous spines), $p m-h$ [powdery mildew (Sphaerotheca fuliginea Schlecht.:Fr.) resistance expressed on the hypocotyl], ss (small spines), $T u$ (tuberculate fruit), $u$ (uniform immature fruit color), and $w$ (white immature fruit color). A major objective of this study was to measure linkages of genes for fruit bitterness (Bt and $B t$ 2 ), and spine color $(B-3$ and $B-4)$ relative to previously studied loci: $B, b i, D, d e, d f, F, g l, l h, n s, p m-h, s s, T u, u$, and $w$. The $F_{2}$ progeny of LJ 90430 x PI 173889 segregated 13 bitter fruit : 3 nonbitter fruit, indicating that different genes are controlling fruit bitterness in these lines. $B t-2$ is proposed as the gene controlling bitterness of fruit in $\mathrm{LJ} 90430$. It is a separate locus from $B t$, that causes bitter fruit in PI 173889. Several new gene linkages were found: $b i-B t,(B t-2)-d e$, $D-(B t-2), D-n s, g l-F, s s-(B t-2), T u-(B t-2)$, and $u-(B t-2)$. The $B t$ gene appears to be linked to $b i$ and may be located on linkage group I. Bt-2 appears to be linked with several genes that could connect linkage groups I and IV. Bt-2 was linked to $u, T u, D$, and $s s$, that are all on linkage group IV. Bt-2 was also found to be linked loosely to de, that is on linkage group I. No linkages were found between $B-3$ and $B-4$ and the genes evaluated in this study. Weak linkages $(>25 \mathrm{cM})$ between several gene combinations $[(B t-2)-d e, d e-n s, d e-s s, d e-T u, d e-u, n s-F$, and $s s-F]$ provided more evidence that linkage group I and IV may be linked. Due to the weak linkages, more information needs to be obtained using larger populations and more markers to confirm these findings.
\end{abstract}

Cucumber (Cucumis sativus) is a diploid species with seven chromosomes. The estimated genomic length of cucumber is 750 to $1000 \mathrm{cM}$ (Staub and Meglic, 1993) with 269 gene mutants [158 classical genes, 91 restriction fragment-length polymorphic (RFLP) markers and 20 randomly amplified polymorphic DNA (RAPD) markers] and six linkage groups reported from linkage studies of the classical genes (Pierce and Wehner, 1990; Wehner, 1993; Wehner and Staub, 1997). Because there are only seven chromosome pairs in cucumber, it should be possible to assemble a linkage map using the gene mutants published. However, much work remains to be done because little has been published on linkage relationships among the known genes.

The six linkage maps of Fanourakis and Simon (1987), Kennard et al. (1994), Knerr and Staub (1992), Meglic and Staub (1996), Serquen et al. (1997), and Vakalounakis (1992) spanned 168, $766,185,584,628$, and $95 \mathrm{cM}$, respectively. Knerr and Staub (1992) assigned 12 of 14 isozyme loci in cucumber to four linkage groups, with a mean interval length of $14 \mathrm{cM}$. Meglic and Staub (1996) found 14 morphological markers to be linked to isozyme

Received for publication 14 Nov. 2000. Accepted for publication 20 Mar. 2001. The research reported in this publication was funded in part by the North Carolina Agricultural Research Service (NCARS), Raleigh, N.C. Use of trade names in this publication does not imply endorsement by the NCARS of the products named, nor criticism of similar ones not mentioned. The authors gratefully acknowledge technical assistance of Tammy L. Ellington. The cost of publishing this paper was defrayed in part by the payment of page charges. Under postal regulations, this paper therefore must be hereby marked advertisement solely to indicate this fact. ${ }^{1}$ Assistant professor.

${ }^{2}$ Assistant plant breeder.

${ }^{3}$ Professor. loci that were integrated to form a map containing four linkage groups (mean linkage distance: $19 \mathrm{cM}$; interval distance between isozyme and morphological markers: $14.8 \mathrm{cM}$ ). Kennard et al. (1994) constructed 58- and 70-point maps using narrow $(C$. sativus $\mathrm{L}$. var. sativus $\mathrm{x}$ C. sativus var. sativus) and wide $[C$. sativus var. sativus $\times$ C. sativus var. hardwickii (Royle) Gabqev] crosses, respectively. Ten linkage groups were identified in cucumber using RFLP markers, RAPD markers, isozymes, morphological markers, and disease resistance markers. The narrow and wide crosses spanned a genomic length of 766 and $480 \mathrm{cM}$ with an average distance between loci of 21 and $8 \mathrm{cM}$, respectively. Serquen et al. (1997) constructed a map using a wide cross of C. sativus var. sativus (G421 x H-19); the map consisted of 80 RAPDs and three morphological marker loci that spanned $\approx 600$ cM over nine linkage groups, with an average distance between marker intervals of $8.4 \mathrm{cM}$. This map has been useful for identifying the location of Female $(F)$, determinate plant habit (de), littleleaf $(l l)$, and quantitative trait loci for yield components.

Little research has been conducted on gene linkage relationships for many of the genes in cucumber. Barham (1953) reported that the bitter fruit character in cucumber PI 173889 was controlled by a single dominant gene, designated $B t$. Cowen and Helsel (1983) found the dominant gene controlling fruit bitterness in LJ 90430 was independent of genes $B-3, B-4$, and $F$. Walters and Wehner (1998) found the gene controlling fruit bitterness in LJ 90430 was inherited as a single dominant gene. However, it is not known if the gene is allelic with $B t$.

The objective of this study was to determine segregation and linkage relationships among 11 crosses in cucumber to facilitate construction of a genetic map in cucumber. A major focus of this 
Table 1. Gene designation and phenotypic description of cucumber lines and cultivars tested.

\begin{tabular}{|c|c|c|c|c|c|c|c|c|c|c|c|c|}
\hline \multirow[b]{3}{*}{ Trait $^{\mathrm{z}}$} & & & \multicolumn{10}{|c|}{ Line or cultivar ${ }^{\mathrm{y}}$} \\
\hline & \multicolumn{2}{|c|}{ Classes } & \multirow{2}{*}{$\begin{array}{l}\text { Cool } \\
\text { green }\end{array}$} & \multirow{2}{*}{$\begin{array}{l}\mathrm{M} \\
21\end{array}$} & \multirow{2}{*}{$\begin{array}{l}\text { Man } \\
\text { teo }\end{array}$} & \multirow{2}{*}{$\begin{array}{c}\text { NCG } \\
90\end{array}$} & \multirow{2}{*}{$\begin{array}{c}\text { NCG } \\
101\end{array}$} & \multirow{2}{*}{$\begin{array}{c}\text { WI } \\
2757\end{array}$} & \multirow{2}{*}{$\begin{array}{c}\text { LJ } \\
90430\end{array}$} & \multirow{2}{*}{$\begin{array}{c}\text { PI } \\
173889 \\
\end{array}$} & \multirow{2}{*}{$\begin{array}{c}\text { NCG } \\
198\end{array}$} & \multirow{2}{*}{$\begin{array}{c}\text { NCG } \\
199\end{array}$} \\
\hline & Dom $(+)$ & res $(-)$ & & & & & & & & & & \\
\hline Bitterfree cotyledons (bi) & Bitter & Non & + & + & + & + & + & - & + & + & + & - \\
\hline Bitter fruit $(B t)$ & Bitter & Non & - & - & - & - & - & - & - & + & - & - \\
\hline Bitter fruit-2 $(B t-2)^{*}$ & Bitter & Non & - & - & - & - & - & - & + & - & + & - \\
\hline Black Spine $(B)$ & Black & White & - & - & - & + & - & - & - & - & - & - \\
\hline Black Spine $3(B-3)$ & Black & White & - & - & - & - & - & - & + & + & + & - \\
\hline Black Spine $4(B-4)$ & Black & White & - & - & - & - & - & - & + & + & - & - \\
\hline Delayed flowering $(d f)$ & Early & Delayed & + & + & + & + & + & - & 0 & + & - & - \\
\hline Determinate $(d e)$ & Long & Short & + & - & + & + & + & + & + & + & + & + \\
\hline Dull fruit skin $(D)$ & Dull & Shiny & - & + & + & + & + & - & + & + & + & - \\
\hline Female $(F)$ & Gyn & Mon & - & - & - & - & - & + & - & - & + & + \\
\hline Glabrous $(g l)$ & Hairy & Hairless & + & + & + & - & + & + & + & + & + & + \\
\hline Long hypocotyl (lh) & Short & Long & + & + & + & + & - & + & + & + & + & + \\
\hline Numerous spines $(n s)$ & Few & Many & - & + & + & + & + & - & + & + & - & - \\
\hline Powdery mildew res. $(p m-h)$ & Suscep & Resist & + & + & + & + & + & - & + & + & + & + \\
\hline Small spines $(s s)$ & Large & Small & - & + & + & + & + & - & + & + & - & - \\
\hline Tuberculate fruit $(T u)$ & Warty & Smooth & - & + & + & + & + & - & + & + & + & - \\
\hline Uniform imm. Frt. color $(u)$ & Speckled & Uniform & - & + & + & + & + & - & + & + & + & - \\
\hline White immature fruit $(w)$ & Green & White & + & + & + & + & - & + & + & + & + & + \\
\hline
\end{tabular}

$\mathrm{Z} *=$ New gene.

$\mathrm{y}(+)$ Dominant, (-) recessive, (0) unknown. All of the lines or cultivars used in this study are maintained in the North Caroina State University Cucurbit Breeding Program.

study was to measure linkage of the genes for fruit bitterness $(B t$ and $B t-2)$ and spine color $(B-3$ and $B-4)$ with several previously studied loci: $B, b i, D, d e, d f, F, g l, l h, n s, p m-h, s s, T u, u$, and $w$.

\section{Materials and Methods}

GERMPLASM. The inbreds used as parents were self-pollinated and checked for uniform expression for the traits of interest. The available gene mutants are curated by T.C. Wehner at North Carolina State University, Raleigh, and the descriptions of the lines used in this study are in Table 1.NCG-198 was selected from the progeny of LJ $90430 \times$ WI 2757 , and is homozygous for $B t$ $2, B-3, d f, F, n s$, and ss. NCG-199 was selected from the progeny of LJ $90430 \times$ WI 2757, and is homozygous for $b i, d, d f, F, n s, s s$, $t u$, and $u$. NCG-90 and NCG-101 were lines obtained from mutant field selections in the North Carolina State University cucurbit breeding program. Crosses were made in the greenhouse using standard pollination techniques for cucumber (Whitaker and Davis, 1962) between several lines to develop $F_{1}$ and $F_{2}$ progeny: WI 2757 x LJ 90430, NCG-198 x NCG-90, NCG-198 x M21, WI 2757 x 'Coolgreen', PI 173889 x NCG-101, PI 173889 x WI 2757, NCG-198 x 'Coolgreen', NCG-198 x NCG-90, NCG-199 x M21, 'Manteo' x M21, and LJ 90430 x PI 173889. Eighteen genes controlling 15 traits were studied in these crosses: $B$ (black spine), $B-3$ (black spine-3), $B-4$ (Black spine-4), $b i$ (bitterfree cotyledons), $B t$ (bitter fruit), $B t-2$ (bitter fruit-2), $D$ (dull fruit skin), $d f$ (delayed flowering), $d e$ (determinate habit), $F$ (female sex expression), $g l$ (glabrous foliage), $l h$ (long hypocotyl), $n s$ (numerous spines), $p m-h$ (powdery mildew resistance expressed in the hypocotyl), $s s$ (small spines), $T u$ (tuberculate fruit), $u$ (uniform immature fruit color), and $w$ (white immature fruit color). Families were evaluated in greenhouses in Raleigh, N.C., at the Horticultural Crops Research Station, Clinton, N.C., or at the Horticultural Research Center, Carbondale, Ill.

Greenhouse EVALuATIONS. Plants were grown in 1.8-L (150- mm-diameter) clay pots on benches in a greenhouse. Two seeds were sown in each pot containing a steam pasteurized medium of 1 sand : 1 soil ( $85 \%$ sand, $10 \%$ silt, $5 \%$ clay) (by volume). Plants were thinned to one per pot at the one-leaf stage. Pots were irrigated twice daily using drip irrigation with fertilizer injection. $\mathrm{F}_{2}$ progeny of WI 2757 x LJ 90430, 'Manteo' x M21, NCG-198 x 'Coolgreen', and NCG-199 x M21 were evaluated for singlyinherited traits that were present.

The $F_{2}$ progeny of WI 2757 x LJ 90430 were inoculated with the powdery mildew pathogen [Sphaerotheca fuliginea (Schlecht.:Fr.)] at the five to seven leaf stage by dusting spores from infected plants onto the plants to be evaluated for three consecutive days (spore concentration was unknown). For evaluation of $p m$ - $h$ segregation, plants were classified as resistant if powdery mildew did not develop on stems or petioles. In those $\mathrm{F}_{2}$ families involving $F$ segregation, gynoecy was defined as those that had continuous female flowers after the ninth node. Plants without flowers up to the fifth node were defined as delayed flowering $(d f)$. Plants were hand-pollinated to obtain fruit for the various fruit traits evaluated.

Field evaluations. Seeds of the parents, $F_{1}$ and $F_{2}$ populations were planted in $57 \times 57-\mathrm{mm}$ square peat pots $(80 \mathrm{~mL}$ volume) containing Metro Mix (Scotts-Sierra Horticultural Products Company, Marysville, Ohio). Field evaluations were conducted during Summers 1995, 1998, and 2000. The 1995 and 1998 evaluations were conducted at the Horticultural Crops Research Station, Clinton, N.C. The 2000 evaluations were conducted at the Horticultural Research Center, Carbondale, Ill. Five families were evaluated in 1995: NCG-198 x M21, WI 2757 X 'Coolgreen', PI 173889 x NCG-101, PI 173889 x WI 2757, and NCG-198 x NCG-90. NCG-199 x M21 was evaluated in 1998, and LJ 90430 x PI 173889 was evaluated in 2000.

For all years, two seeds were sown in each pot and thinned to one seedling at the early cotyledon stage. At the same time, data of seedling traits were collected for certain families. After the 
Table 2. Linkage relations of several genes in cucumber.

\begin{tabular}{|c|c|c|c|c|c|c|c|c|c|c|}
\hline \multirow{2}{*}{$\begin{array}{l}\text { Family/ } \\
\text { gene pair }\end{array}$} & \multirow[b]{2}{*}{ Generation } & \multicolumn{5}{|c|}{ Plants (no.) } & \multirow{2}{*}{$\begin{array}{l}\text { Chi- } \\
\text { square }\end{array}$} & \multirow{2}{*}{$\begin{array}{c}P \\
\text { value }\end{array}$} & \multirow{2}{*}{$\begin{array}{l}\text { Map } \\
\text { units }^{\mathrm{z}}\end{array}$} & \multirow[b]{2}{*}{$\mathrm{SE}^{\mathrm{y}}$} \\
\hline & & A_B_ & A_bb & $\mathrm{aaB}$ & aabb & Total & & & & \\
\hline \multicolumn{11}{|c|}{ WI 2757 x LJ 90430} \\
\hline$d f-D$ & $\mathrm{~F}_{2}$ & 95 & 26 & 24 & 8 & 153 & 2.2 & 0.53 & I & \\
\hline$d f-n s$ & $\mathrm{~F}_{2}^{2}$ & 84 & 37 & 29 & 3 & 153 & 7.0 & 0.07 & I & \\
\hline$d f-s s$ & $\mathrm{~F}_{2}^{2}$ & 81 & 40 & 26 & 6 & 153 & 6.3 & 0.09 & I & \\
\hline$d f-T u$ & $\mathrm{~F}_{2}$ & 93 & 28 & 26 & 6 & 153 & 2.2 & 0.54 & I & \\
\hline$d f-u$ & $\mathrm{~F}_{2}$ & 98 & 23 & 24 & 8 & 153 & 3.8 & 0.28 & $\mathrm{I}$ & \\
\hline$F-D$ & $\mathrm{~F}_{2}$ & 92 & 28 & 27 & 6 & 153 & 1.9 & 0.6 & I & \\
\hline$F-d f$ & $\mathrm{~F}_{2}$ & 103 & 19 & 19 & 19 & 160 & 18.0 & $>0.005$ & 28.4 & 3.4 \\
\hline$F-n s$ & $\mathrm{~F}_{2}$ & 86 & 34 & 27 & 6 & 153 & 2.4 & 0.49 & I & \\
\hline$F-s s$ & $\mathrm{~F}_{2}$ & 78 & 42 & 29 & 4 & 153 & 10.2 & 0.02 & 31.5 & 5.2 \\
\hline$F-T u$ & $\mathrm{~F}_{2}$ & 94 & 26 & 25 & 8 & 153 & 1.7 & 0.63 & I & \\
\hline$F-u$ & $\mathrm{~F}_{2}^{2}$ & 95 & 25 & 27 & 6 & 153 & 2.8 & 0.41 & I & \\
\hline$n s-D$ & $\mathrm{~F}_{2}$ & 89 & 24 & 30 & 10 & 153 & 0.9 & 0.81 & I & \\
\hline$n s-\mathrm{ss}$ & $\mathrm{F}_{2}^{2}$ & 94 & 19 & 13 & 27 & 153 & 44.4 & $>0.005$ & 22.1 & 3.1 \\
\hline$n s-T u$ & $\mathrm{~F}_{2}$ & 90 & 23 & 29 & 11 & 153 & 1.5 & 0.67 & I & \\
\hline$n s-u$ & $\mathrm{~F}_{2}$ & 90 & 23 & 32 & 8 & 153 & 1.9 & 0.58 & I & \\
\hline$(p m-h)-D$ & $\mathrm{~F}_{2}$ & 90 & 19 & 29 & 15 & 153 & 6.5 & 0.08 & I & \\
\hline$(p m-h)-d f$ & $\mathrm{~F}_{2}$ & 85 & 31 & 37 & 7 & 160 & 2.8 & 0.41 & I & \\
\hline$(p m-h)-F$ & $\mathrm{~F}_{2}$ & 89 & 27 & 33 & 11 & 160 & 0.7 & 0.87 & I & \\
\hline$(p m-h)-n s$ & $\mathrm{~F}_{2}$ & 84 & 25 & 29 & 15 & 153 & 3.6 & 0.3 & I & \\
\hline$(p m-h)-s s$ & $\mathrm{~F}_{2}$ & 79 & 30 & 28 & 16 & 153 & 5.0 & 0.17 & I & \\
\hline$(p m-h)-T u$ & $\mathrm{~F}_{2}$ & 91 & 18 & 28 & 16 & 153 & 8.6 & 0.03 & 35.7 & 3.9 \\
\hline$(p m-h)-u$ & $\mathrm{~F}_{2}$ & 95 & 14 & 27 & 17 & 153 & 14.3 & $>0.005$ & 31.1 & 3.6 \\
\hline$s s-D$ & $\mathrm{~F}_{2}$ & 96 & 11 & 23 & 23 & 153 & 32.1 & $>0.005$ & 23.6 & 3.2 \\
\hline$s s-T u$ & $\mathrm{~F}_{2}^{2}$ & 98 & 9 & 21 & 25 & 153 & 42.1 & $>0.005$ & 20.0 & 2.9 \\
\hline$s s-u$ & $\mathrm{~F}_{2}$ & 99 & 8 & 23 & 23 & 153 & 36.9 & $>0.005$ & 20.4 & 2.9 \\
\hline$T u-D$ & $\mathrm{~F}_{2}$ & 109 & 10 & 10 & 24 & 153 & 52.3 & $>0.005$ & 14.8 & 2.5 \\
\hline$T u-u$ & $\mathrm{~F}_{2}$ & 115 & 4 & 7 & 27 & 153 & 79.2 & $>0.005$ & 7.7 & 1.8 \\
\hline$u-D$ & $\mathrm{~F}_{2}$ & 115 & 7 & 4 & 27 & 153 & 79.2 & $>0.005$ & 7.7 & 1.8 \\
\hline
\end{tabular}

Continued next page.

seedling tests were completed, plants were transplanted to the field for evaluation of vegetative, flowering, and fruiting traits. Plants were evaluated for the genes present biweekly. Fertilization and pest control practices were followed for cucumber production in North Carolina (College of Agriculture and Life Sciences, 1995; College of Agriculture and Life Sciences, 1998) and Illinois (Foster et al., 2000).

DATA ANALYSIS. The SASGENE 1.2 program (Liu et al., 1997) is a SAS (SAS Inst. Inc., Cary, N.C.) computer program for analysis of gene segregation and linkage relationships and allows the following calculations: 1) single-gene or two-gene goodnessof-fit tests, which are based on comparisons of observed frequency data with the expected Mendelian segregation ratios for $\mathrm{F}_{2}$ and $\mathrm{BC}_{1}$ generation data; 2 ) chi-square and probability values, analyzed for independent assortment or linkage likelihood; and 3) recombination frequencies (rf) and standard errors (SES), which were calculated according to coupling or repulsion phase (Sinnot and Dunn, 1939; Weir, 1994).

\section{Results and Discussion}

Single LOCUS GOODNESS-OF-FIT TEST. The single gene goodness-of-fit test indicated that all genes studied fit a single gene model (data not presented), except $B t, B t-2, B-3$, and $B-4$, which were found to be segregating in the ratio of $9: 7$ in the $F_{2}$ generation and in some cases did not fit the single gene model. The $F_{2}$ progeny of LJ 90430 x PI 173889 provided some insight into the genetic control of $B t$ and $B t-2$, as the fruit segregated 232 bitter : 42 nonbitter. This did not fit a 15:1 ratio as expected, but fit a 13:3 ratio. The 13:3 ratio indicates there is dominant and recessive epistasis, where the dominant allele masks the expression of both the alleles at a second locus, while a recessive allele at the second locus masks the expression of alleles at the first locus and produces an identical phenotype as the dominant allele. We therefore propose $B t-2$, as the gene controlling bitter fruit in $\mathrm{LJ}$ 90430. It is similar in action to the Bt gene described by Barham (1953) that controls bitter fruit in PI 173889. The $F_{2}$ progeny of LJ $90430 \times$ PI 173889 did not segregate with respect to spine color indicating that the same genes $(B-3$ and $B-4)$ were present in both parents (data not presented).

The cucumber cultigens 'Coolgreen' and WI 2757 have similar characteristics with white, small, numerous spines, and glossy, tender, uniform green fruit. This study indicated that $B, n s, s s, T u$, te, $u$, and $D$ genes were identical in WI 2757 and 'Coolgreen' because the genes did not segregate in the $\mathrm{F}_{2}$ progeny (data not presented).

UNLINKED GENES. Most of the gene pairs studied segregated independently. However, some of the genes were linked (Tables $2,3,4,5,6$, and 7$)$. The gene pairs that segregated independently were $B-3-B t-2, B-3-d e, B-3-n s, B-3-s s, b i-D, b i-d f, b i-$ $F, b i-n s, b i-s s, b i-T u, b i-u, D-B-3, d f-B-3, d f-B t-2$, $d f-D, d f-n s, d f-s s, d f-T u, d f-u, F-B-3, F-B t-2, F-D$, $F-n s, F-s s, F-T u, F-u, l h-B, l h-B t, l h-w, n s-B t-2$, $\mathrm{ns}-D, n s-T u, n s-u, p m-h-D, p m-h-d f, p m-h-F, p m-h-$ 
Table 2. Continued.

\begin{tabular}{|c|c|c|c|c|c|c|c|c|c|c|}
\hline \multirow{2}{*}{$\begin{array}{l}\text { Family/ } \\
\text { gene pair }\end{array}$} & \multirow[b]{2}{*}{ Generation } & \multicolumn{5}{|c|}{ Plants (no.) } & \multirow{2}{*}{$\begin{array}{l}\text { Chi- } \\
\text { square }\end{array}$} & \multirow{2}{*}{$\begin{array}{c}P \\
\text { value }\end{array}$} & \multirow{2}{*}{$\begin{array}{l}\text { Map } \\
\text { units }^{\mathrm{z}}\end{array}$} & \multirow[b]{2}{*}{$\mathrm{SE}^{\mathrm{y}}$} \\
\hline & & A_B_ & A_bb & $\mathrm{aaB}$ & aabb & Total & & & & \\
\hline \multicolumn{11}{|c|}{ NCG-198 x NCG-90 } \\
\hline$g l-F$ & $\mathrm{~F}_{2}$ & 79 & 13 & 6 & 20 & 118 & 39.5 & $>0.005$ & 16.6 & 3.0 \\
\hline \multicolumn{11}{|l|}{ NCG-198 x M21 } \\
\hline$(B-3)-(B t-2)$ & $\mathrm{F}_{2}$ & 85 & 27 & 25 & 4 & 141 & 3.1 & 0.37 & I & \\
\hline$(B-3)-d e$ & $\mathrm{~F}_{2}$ & 75 & 35 & 19 & 9 & 138 & 5.1 & 0.16 & I & \\
\hline$(B-3)-n s$ & $\mathrm{~F}_{2}$ & 77 & 35 & 23 & 7 & 142 & 3.6 & 0.30 & I & \\
\hline$(B-3)-s s$ & $\mathrm{~F}_{2}^{2}$ & 76 & 36 & 22 & 8 & 142 & 4.4 & 0.22 & I & \\
\hline$(B t-2)-d e$ & $\mathrm{~F}_{2}$ & 78 & 28 & 15 & 16 & 137 & 11.1 & 0.01 & 35.4 & 4.1 \\
\hline$d f-(B-3)$ & $\mathrm{F}_{2}$ & 85 & 19 & 26 & 9 & 139 & 2.5 & 0.47 & I & \\
\hline$d f-(B t-2)$ & $\mathrm{F}_{2}$ & 78 & 25 & 29 & 6 & 138 & 1.2 & 0.75 & I & \\
\hline$d f-d e$ & $\mathrm{~F}_{2}$ & 57 & 44 & 34 & 0 & 135 & 29.9 & $>0.005$ & 0.0 & 0.0 \\
\hline$d f-F$ & $\mathrm{~F}_{2}^{2}$ & 71 & 33 & 33 & 2 & 139 & 9.5 & 0.02 & 23.8 & 5.7 \\
\hline$d f-n s$ & $\mathrm{~F}_{2}$ & 72 & 32 & 26 & 9 & 139 & 1.9 & 0.60 & I & \\
\hline$d f-s s$ & $\mathrm{~F}_{2}$ & 71 & 33 & 25 & 10 & 139 & 2.7 & 0.43 & I & \\
\hline$F-(B-3)$ & $\mathrm{F}_{2}$ & 86 & 21 & 26 & 9 & 142 & 1.7 & 0.64 & I & \\
\hline$F-(B t-2)$ & $\mathrm{F}_{2}$ & 85 & 22 & 25 & 9 & 141 & 1.2 & 0.74 & I & \\
\hline$F-d e$ & $\mathrm{~F}_{2}$ & 85 & 21 & 10 & 23 & 139 & 35.1 & $>0.005$ & 23.0 & 3.3 \\
\hline$F-n s$ & $\mathrm{~F}_{2}$ & 72 & 35 & 28 & 7 & 142 & 3.9 & 0.27 & I & \\
\hline$F-s s$ & $\mathrm{~F}_{2}$ & 69 & 38 & 29 & 6 & 142 & 7.5 & 0.06 & I & \\
\hline$n s-(B t-2)$ & $\mathrm{F}_{2}$ & 80 & 19 & 30 & 12 & 141 & 3.7 & 0.29 & I & \\
\hline$n s-d e$ & $\mathrm{~F}_{2}$ & 61 & 36 & 33 & 8 & 138 & 9.5 & 0.02 & 37.6 & 5.3 \\
\hline$n s-s s$ & $\mathrm{~F}_{2}$ & 96 & 4 & 2 & 40 & 142 & 154.4 & $>0.005$ & 3.8 & 1.3 \\
\hline$s s-(B t-2)$ & $\mathrm{F}_{2}$ & 79 & 18 & 31 & 13 & 141 & 5.5 & 0.14 & I & \\
\hline$s s-d e$ & $\mathrm{~F}_{2}$ & 58 & 36 & 36 & 8 & 138 & 12.9 & $>0.005$ & 35.8 & 5.3 \\
\hline \multicolumn{11}{|c|}{ PI 173889 x WI 2757} \\
\hline$b i-D$ & $\mathrm{~F}_{2}$ & 69 & 34 & 36 & 8 & 147 & 6.5 & 0.08 & I & \\
\hline$b i-F$ & $\mathrm{~F}_{2}$ & 76 & 27 & 36 & 8 & 147 & 3.3 & 0.34 & I & \\
\hline$b i-n s$ & $\mathrm{~F}_{2}$ & 85 & 18 & 35 & 9 & 147 & 5.4 & 0.14 & I & \\
\hline$b i-s s$ & $\mathrm{~F}_{2}$ & 73 & 30 & 33 & 11 & 147 & 2.8 & 0.42 & I & \\
\hline$b i-T u$ & $\mathrm{~F}_{2}$ & 70 & 33 & 32 & 12 & 147 & 4.6 & 0.20 & I & \\
\hline$b i-u$ & $\mathrm{~F}_{2}$ & 75 & 28 & 35 & 9 & 147 & 2.7 & 0.43 & I & \\
\hline$D — n s$ & $\mathrm{~F}_{2}$ & 92 & 13 & 28 & 14 & 147 & 11.3 & 0.01 & 33.3 & 3.8 \\
\hline$D-s s$ & $\mathrm{~F}_{2}$ & 88 & 17 & 18 & 24 & 147 & 31.6 & $>0.005$ & 25.9 & 3.4 \\
\hline$D-T u$ & $\mathrm{~F}_{2}$ & 94 & 11 & 8 & 34 & 147 & 92.4 & $>0.005$ & 12.8 & 2.4 \\
\hline$D-u$ & $\mathrm{~F}_{2}$ & 97 & 8 & 13 & 29 & 147 & 66.8 & $>0.005$ & 14.6 & 2.5 \\
\hline$F-D$ & $\mathrm{~F}_{2}$ & 79 & 33 & 26 & 9 & 147 & 1.3 & 0.72 & I & \\
\hline$F-n s$ & $\mathrm{~F}_{2}$ & 91 & 21 & 29 & 6 & 147 & 3.6 & 0.31 & I & \\
\hline$F-s S$ & $\mathrm{~F}_{2}$ & 79 & 33 & 27 & 8 & 147 & 1.4 & 0.70 & I & \\
\hline$F-T u$ & $\mathrm{~F}_{2}$ & 77 & 35 & 25 & 10 & 147 & 2.7 & 0.43 & I & \\
\hline$F-u$ & $\mathrm{~F}_{2}$ & 82 & 30 & 28 & 7 & 147 & 0.7 & 0.86 & I & \\
\hline$n s-s s$ & $\mathrm{~F}_{2}$ & 103 & 17 & 3 & 24 & 147 & 54.8 & $>0.005$ & 11.3 & 2.2 \\
\hline$n s-T u$ & $\mathrm{~F}_{2}$ & 87 & 33 & 15 & 12 & 147 & 7.9 & 0.05 & 39.8 & 4.1 \\
\hline$n s-u$ & $\mathrm{~F}_{2}$ & 89 & 31 & 21 & 6 & 147 & 3.6 & 0.31 & I & \\
\hline$s s-T u$ & $\mathrm{~F}_{2}$ & 87 & 19 & 15 & 26 & 147 & 39.4 & $>0.005$ & 24.5 & 3.3 \\
\hline$s s-u$ & $\mathrm{~F}_{2}$ & 87 & 19 & 23 & 18 & 147 & 12.1 & 0.01 & 33.1 & 3.8 \\
\hline$T u-u$ & $\mathrm{~F}_{2}$ & 100 & 2 & 10 & 35 & 147 & 111.0 & $>0.005$ & 6.2 & 1.7 \\
\hline
\end{tabular}

Continued next page.

$n s, p m-h-s s, s s-B t-2, T u-B-3, u-B-3, w-B t, B-w$, and $B-$ Bt (Table 2).

The two spine color genes ( $B-3$ and $B-4)$ segregated independently, with a ratio of 9:7 for the following gene pair combinations: $(B-3$ and $B-4)-l h,(B-3$ and $B-4)-w,(B-3$ and $B-4)-B t$ $2,(B-3$ and $B-4)-d f,(B-3$ and $B-4)-F,(B-3$ and $B-4)-p m-h$, $(B-3$ and $B-4)-n s,(B-3$ and $B-4)-s s,(B-3$ and $B-4)-T u,(B-3$ and $B-4)-u$, and $(B-3$ and $B-4)-D$ (Table 3$)$. Spine color $(B-3$ and $B-4$ ) was also found to be segregating independently in the ratio of 9:7 for the following gene pair combinations in the $\mathrm{F}_{2}$ progeny of PI $173889 \times$ WI 2757 : $(B-3$ and $B-4)-b i,(B-3$ and $B$ -
4) $-B t,(B-3$ and $B-4)-F,(B-3$ and $B-4)-D,(B-3$ and $B-4)-$ $n s,(B-3$ and $B-4)-s s,(B-3$ and $B-4)-T u$, and $(B-3$ and $B-4)-$ $u$ (Table 4). No linkages were found between $B-3$ or $B-4$ and the other genes evaluated. Fruit bitterness $(B t-2)$ was found to segregate independently with a ratio of 9:7 (due to the interaction with $b i$ as discussed by Walters and Wehner, 1998) for the following gene pair combinations: $B t-2-D, B t-2-d f, B t-2-F$, $B t-2-p m-h, B t-2-n s, B t-2-s s, B t-2-T u, B t-2-u, B t-2-g l$, and $B t-2-F$ (Table 5). Linkage relationships of fruit bitterness $(B t)$ were found to be segregating independently in the ratio of 1:1 for the following gene pair combinations: $B t-b i, B t-F$, 
Table 2. Continued.

\begin{tabular}{|c|c|c|c|c|c|c|c|c|c|c|}
\hline \multirow{2}{*}{$\begin{array}{l}\text { Family/ } \\
\text { gene pair }\end{array}$} & \multirow[b]{2}{*}{ Generation } & \multicolumn{5}{|c|}{ Plants (no.) } & \multirow{2}{*}{$\begin{array}{l}\text { Chi- } \\
\text { square }\end{array}$} & \multirow{2}{*}{$\begin{array}{c}P \\
\text { value }\end{array}$} & \multirow{2}{*}{$\begin{array}{l}\text { Map } \\
\text { units }^{\mathrm{z}}\end{array}$} & \multirow[b]{2}{*}{$\mathrm{SE}^{\mathrm{y}}$} \\
\hline & & A_B_ & A_bb & $\mathrm{aaB}_{-}$ & aabb & Total & & & & \\
\hline \multicolumn{11}{|c|}{ PI 173889 x NCG-101 } \\
\hline$B-B t$ & $\mathrm{~F}_{2}$ & 86 & 30 & 24 & 11 & 151 & 1.0 & 0.79 & I & \\
\hline$B-w$ & $\mathrm{~F}_{2}$ & 97 & 22 & 27 & 8 & 154 & 3.3 & 0.37 & I & \\
\hline$l h-B$ & $\mathrm{~F}_{2}$ & 86 & 25 & 33 & 10 & 154 & 1.1 & 0.77 & I & \\
\hline$l h-B t$ & $\mathrm{~F}_{2}$ & 78 & 31 & 32 & 10 & 151 & 1.3 & 0.72 & I & \\
\hline$l h-w$ & $\mathrm{~F}_{2}$ & 89 & 22 & 35 & 8 & 154 & 3.3 & 0.37 & I & \\
\hline$w-B t$ & $\mathrm{~F}_{2}$ & 89 & 33 & 21 & 8 & 151 & 3.1 & 0.40 & I & \\
\hline \multicolumn{11}{|c|}{ NCG-198 x Coolgreen } \\
\hline$(B-3)-(B t-2)$ & $\mathrm{F}_{2}$ & 65 & 26 & 18 & 11 & 120 & 3.2 & 0.36 & I & \\
\hline$D-(B-3)$ & $\mathrm{F}_{2}$ & 63 & 21 & 28 & 8 & 120 & 1.8 & 0.61 & I & \\
\hline$D-(B t-2)$ & $\mathrm{F}_{2}$ & 76 & 8 & 7 & 29 & 120 & 82.7 & $>0.005$ & 12.4 & 2.6 \\
\hline$D-T u$ & $\mathrm{~F}_{2}$ & 72 & 12 & 21 & 15 & 120 & 12.8 & 0.01 & 31.0 & 4.1 \\
\hline$T u-(B-3)$ & $\mathrm{F}_{2}$ & 71 & 22 & 20 & 7 & 120 & 0.5 & 0.91 & I & \\
\hline$T u-(B t-2)$ & $\mathrm{F}_{2}$ & 75 & 18 & 8 & 19 & 120 & 28.7 & $>0.005$ & 22.4 & 3.5 \\
\hline$u-(B-3)$ & $\mathrm{F}_{2}$ & 66 & 19 & 25 & 10 & 120 & 1.7 & 0.63 & I & \\
\hline$u-(B t-2)$ & $\mathrm{F}_{2}$ & 81 & 4 & 2 & 33 & 120 & 123.3 & $>0.005$ & 4.6 & 1.6 \\
\hline$u-D$ & $\mathrm{~F}_{2}$ & 78 & 7 & 6 & 29 & 120 & 86.0 & $>0.005$ & 10.7 & 2.4 \\
\hline$u-T u$ & $\mathrm{~F}_{2}$ & 78 & 7 & 15 & 20 & 120 & 35.6 & $>0.005$ & 18.9 & 3.2 \\
\hline \multicolumn{11}{|c|}{ WI 2757 x Coolgreen } \\
\hline$b i-d f$ & $\mathrm{~F}_{2}$ & 67 & 22 & 22 & 13 & 124 & 3.8 & 0.28 & I & \\
\hline$b i-F$ & $\mathrm{~F}_{2}$ & 63 & 25 & 28 & 6 & 122 & 2.2 & 0.54 & I & \\
\hline$d f-F$ & $\mathrm{~F}_{2}$ & 58 & 31 & 33 & 0 & 122 & 16.6 & 0.00 & 0.0 & 0.0 \\
\hline \multicolumn{11}{|l|}{ NCG-199 x M21 } \\
\hline$d e-D$ & $\mathrm{~F}_{2}$ & 43 & 0 & 26 & 0 & 69 & 30.9 & 0.000 & 0.0 & 0.0 \\
\hline$d e-F$ & $\mathrm{~F}_{2}^{2}$ & 75 & 10 & 43 & 17 & 145 & 27.5 & $>0.005$ & 35.4 & 5.1 \\
\hline$d e-n s$ & $\mathrm{~F}_{2}$ & 55 & 30 & 36 & 23 & 144 & 33.5 & $>0.005$ & 52.2 & 6.1 \\
\hline$d e-s s$ & $\mathrm{~F}_{2}$ & 51 & 34 & 36 & 23 & 144 & 37.7 & $>0.005$ & 49.4 & 6.3 \\
\hline$d e-T u$ & $\mathrm{~F}_{2}$ & 16 & 27 & 13 & 13 & 69 & 46.2 & $>0.005$ & 42.6 & 9.7 \\
\hline$d e-u$ & $\mathrm{~F}_{2}$ & 63 & 22 & 45 & 14 & 144 & 19.7 & $>0.005$ & 48.4 & 6.4 \\
\hline$F-D$ & $\mathrm{~F}_{2}$ & 57 & 0 & 12 & 0 & 69 & 25.8 & 0.000 & 0.0 & 0.0 \\
\hline$F-n s$ & $\mathrm{~F}_{2}$ & 72 & 45 & 19 & 8 & 144 & 15.5 & $>0.005$ & 44.4 & 6.6 \\
\hline$F-s s$ & $\mathrm{~F}_{2}$ & 69 & 48 & 18 & 9 & 144 & 21.1 & $>0.005$ & 45.3 & 6.6 \\
\hline$F-T u$ & $\mathrm{~F}_{2}$ & 26 & 31 & 3 & 9 & 69 & 42.2 & $>0.005$ & 62.5 & 7.7 \\
\hline$F-u$ & $\mathrm{~F}_{2}$ & 91 & 26 & 17 & 10 & 144 & 5.1 & 0.16 & I & \\
\hline$n s-D$ & $\mathrm{~F}_{2}$ & 49 & 0 & 22 & 0 & 71 & 25.5 & 0.000 & 0.0 & 0.0 \\
\hline$n s-s s$ & $\mathrm{~F}_{2}$ & 86 & 6 & 2 & 53 & 147 & 249.6 & $>0.005$ & 4.3 & 1.7 \\
\hline$n s-T u$ & $\mathrm{~F}_{2}$ & 28 & 21 & 2 & 20 & 71 & 72.2 & $>0.005$ & 19.8 & 5.4 \\
\hline$s s-D$ & $\mathrm{~F}_{2}$ & 45 & 0 & 26 & 0 & 71 & 30.5 & 0.000 & 0.0 & 0.0 \\
\hline$s s-T u$ & $\mathrm{~F}_{2}$ & 29 & 16 & 1 & 25 & 71 & 110.2 & $>0.005$ & 11.6 & 4.1 \\
\hline$T u-D$ & $\mathrm{~F}_{2}$ & 30 & 0 & 41 & 0 & 71 & 77.8 & 0.000 & 0.0 & 0.0 \\
\hline$u-D$ & $\mathrm{~F}_{2}$ & 52 & 0 & 19 & 0 & 71 & 23.8 & 0.000 & 0.0 & 0.0 \\
\hline$u-n s$ & $\mathrm{~F}_{2}$ & 69 & 41 & 23 & 14 & 147 & 12.1 & 0.007 & 49.7 & 6.2 \\
\hline$u-s s$ & $\mathrm{~F}_{2}$ & 70 & 40 & 18 & 19 & 147 & 21.4 & $>0.005$ & 41.5 & 5.6 \\
\hline$u-T u$ & $\mathrm{~F}_{2}$ & 29 & 23 & 1 & 18 & 71 & 62.9 & $>0.005$ & 15.8 & 4.8 \\
\hline
\end{tabular}

${ }_{\mathrm{Z}} \mathrm{I}=$ independent segregation.

${ }^{y_{\mathrm{SE}}}=$ standard error.

$B t-D, B t-n s, B t-s s, B t-T u$, and $B t-u$ (Table 6).

LINKAGE CONFIRMATIONS AND NEWLY DETECTED LINKAGES. The following genes were found to be linked: $b i-B t, B t-2-d e, D-$ $B t-2, D-d e, D-F, D-n s, D-s s, D-T u, D-u, d e-F, d e-$ $n s, d e-s s, d e-T u, d e-u, d f-F, d f-d e, F-n s, F-s s, g l-F$, $n s-s s, n s-T u, p m-h-T u, p m-h-u, s s-B t-2, s s-T u, s s-u$, $T u-B t-2, T u-u, u-B t-2, u-n s, u-s s$, and $u-T u$ (Table 7). Several of these linked genes $(b i-B t, B t-2-d e, D-B t-2, D-$ $n s, g l-F, s s-B t-2, T u-B t-2$, and $u-B t-2)$ have not been reported (Pierce and Wehner, 1990).

The gene $B t-2$ has not been studied previously and is linked with genes that have strategic importance in the cucumber linkage map. The gene Bt-2 was found in LJ 90430, an accession of Cucumis sativus var. hardwickii. In this study, Bt-2 appeared to be linked with several genes in linkage groups I and IV, that were discussed by Pierce and Wehner (1990) (Fig. 1). Bt-2 is linked with the uniform green gene $(u)$ and with other genes $(T u, D$, and $s s$ ) in that region of linkage group VI. Bt-2 was also found to be linked to $d e$, which is on linkage group I, but was not linked to $d f$ or $F$ that are also on linkage group I.

$B t-2$ was not linked to $l h$ indicating that it was not in linkage group V. The Bt gene was found to be linked to bi (Table 6) and, 
Table 3. Linkage relationship of spine color in LJ 90430 (B-3 and B-4) with several other genes in cucumber.

\begin{tabular}{|c|c|c|c|c|c|c|}
\hline \multirow[b]{2}{*}{ Family/gene } & \multicolumn{2}{|c|}{ Spine color } & \multirow[b]{2}{*}{ Total } & \multirow{2}{*}{$\begin{array}{l}\text { Chi- } \\
\text { square }\end{array}$} & \multirow{2}{*}{$\begin{array}{c}P \\
\text { value }\end{array}$} & \multirow[b]{2}{*}{$\mathrm{GA}^{\mathrm{z}}$} \\
\hline & Black & White & & & & \\
\hline \multicolumn{7}{|l|}{ NCG-101 x LJ 90430} \\
\hline$B t-2$ & 76 & 44 & 120 & & & \\
\hline$b t-2$ & 22 & 14 & 36 & 3.14 & 0.39 & I \\
\hline$D f$ & 72 & 44 & 116 & & & \\
\hline$d f$ & 26 & 14 & 40 & 2.89 & 0.42 & I \\
\hline$L h$ & 72 & 45 & 117 & & & \\
\hline$l h$ & 26 & 13 & 39 & 3.05 & 0.40 & I \\
\hline$W$ & 70 & 46 & 116 & & & \\
\hline$w$ & 28 & 12 & 40 & 3.97 & 0.27 & I \\
\hline Total (9:7 segregation) & 98 & 58 & 156 & 2.74 & 0.10 & \\
\hline \multicolumn{7}{|l|}{ WI 2757 x LJ 90430} \\
\hline$F$ & 74 & 46 & 120 & & & \\
\hline$f$ & 22 & 12 & 34 & 3.06 & 0.40 & I \\
\hline$D f$ & 76 & 45 & 121 & & & \\
\hline$d f$ & 20 & 13 & 33 & 3.48 & 0.34 & I \\
\hline$P m-h$ & 73 & 37 & 110 & & & \\
\hline$p m-h$ & 23 & 21 & 44 & 5.72 & 0.14 & I \\
\hline Total (9:7 segregation) & 96 & 58 & 154 & 2.32 & 0.14 & \\
\hline$B t-2$ & 59 & 32 & 91 & & & \\
\hline$b t-2$ & 37 & 25 & 62 & 3.80 & 0.30 & I \\
\hline$D$ & 76 & 43 & 119 & & & \\
\hline$d$ & 20 & 14 & 34 & 3.62 & 0.32 & I \\
\hline Ns & 68 & 41 & 109 & & & \\
\hline$n s$ & 28 & 16 & 44 & 3.85 & 0.29 & I \\
\hline Ss & 68 & 39 & 107 & & & \\
\hline ss & 28 & 18 & 46 & 4.73 & 0.21 & I \\
\hline$T u$ & 76 & 43 & 119 & & & \\
\hline$t u$ & 20 & 14 & 34 & 3.62 & 0.32 & I \\
\hline$U$ & 77 & 45 & 122 & & & \\
\hline$u$ & 19 & 12 & 31 & 4.58 & 0.22 & I \\
\hline Total (9:7 segregation) & 96 & 57 & 153 & 2.62 & 0.11 & \\
\hline
\end{tabular}

${ }^{\mathrm{z}} \mathrm{GA}$ is gene assortment during the $\mathrm{F}_{2}$ generation where single genes should segregate in a $27 \mathrm{~A}_{-} \mathrm{B}_{-}: 21 \mathrm{~A} \_\mathrm{bb}: 9$ aaB_ $: 7$ aabb ratio when a 9:7 segregation ratio was being compared to $3: 1$ segregation ratio. However, for the $B t-2$ gene a 9:7 ratio was compared to a 9:7 ratio and should yield a 81 A_B_ : 63 A_bb : $63 \mathrm{aaB}_{-}$: 49 aabb ratio. All genes segregated independently (I) with $B-3$ and $B-4$. I = independent segregation.

Table 4. Linkage relationship of spine color $(B-3$ and $B-4)$ in PI 173889 with several other genes in cucumber.

\begin{tabular}{|c|c|c|c|c|c|c|}
\hline \multirow[b]{2}{*}{ Family/gene } & \multicolumn{2}{|c|}{ Spine color } & \multirow[b]{2}{*}{ Total } & \multirow{2}{*}{$\begin{array}{l}\text { Chi- } \\
\text { square }\end{array}$} & \multirow{2}{*}{$\begin{array}{c}P \\
\text { value }\end{array}$} & \multirow[b]{2}{*}{$\mathrm{GA}^{2}$} \\
\hline & Black & White & & & & \\
\hline \multicolumn{7}{|l|}{ PI $173889 \times$ WI 2757} \\
\hline$B i$ & 61 & 45 & 106 & & & \\
\hline$b i$ & 30 & 15 & 45 & 4.29 & 0.24 & $\mathrm{I}$ \\
\hline$B t$ & 44 & 32 & 76 & & & \\
\hline$b t$ & 47 & 28 & 75 & 1.42 & 0.71 & I \\
\hline$D$ & 67 & 39 & 106 & & & \\
\hline$d$ & 24 & 21 & 45 & 4.00 & 0.27 & $\mathrm{I}$ \\
\hline$F$ & 72 & 44 & 116 & & & \\
\hline$f$ & 19 & 16 & 35 & 1.72 & 0.64 & $\mathrm{I}$ \\
\hline Ns & 73 & 50 & 123 & & & \\
\hline$n s$ & 18 & 10 & 28 & 4.41 & 0.23 & I \\
\hline Ss & 70 & 39 & 109 & & & \\
\hline ss & 21 & 21 & 42 & 4.10 & 0.25 & $\mathrm{I}$ \\
\hline$T u$ & 67 & 37 & 104 & & & \\
\hline$t u$ & 24 & 23 & 47 & 6.27 & 0.10 & $\mathrm{I}$ \\
\hline$U$ & 69 & 43 & 112 & & & \\
\hline$u$ & 22 & 17 & 39 & 1.35 & 0.72 & $\mathrm{I}$ \\
\hline Total (9:7 segregation) & 91 & 60 & 151 & 0.99 & 0.35 & \\
\hline
\end{tabular}

${ }^{\mathrm{z}} \mathrm{GA}$ is gene assortment during the $\mathrm{F}_{2}$ generation where single genes should segregate in a 27 A_B_ $: 21$ A_bb : 9 aaB_ $: 7$ aabb ratio when a 9:7 segregation ratio was being compared to $3: 1$ segregation ratio. However, for the $B t$ gene a 9:7 ratio was compared to a 1:1 ratio and should yield a 9 A_B_: 7 A_bb : 9 aaB_: 7 aabb ratio. All genes segregated independently (I) with $B-3$ and $B-4$. I = independent segregation. 
Table 5. Linkage relationship of fruit bitterness in LJ 90430 (Bt-2) with several other genes.

\begin{tabular}{|c|c|c|c|c|c|c|c|}
\hline \multirow[b]{2}{*}{ Cross } & \multicolumn{2}{|c|}{ Fruit bitterness } & \multirow[b]{2}{*}{ Total } & \multirow{2}{*}{$\begin{array}{l}\text { Chi- } \\
\text { square }\end{array}$} & \multirow{2}{*}{$\begin{array}{c}P \\
\text { value }\end{array}$} & \multirow{2}{*}{$\begin{array}{c}\text { Map } \\
\text { units }^{z}\end{array}$} & \multirow[b]{2}{*}{$\mathrm{SE}^{\mathrm{y}}$} \\
\hline & Bitter & Nonbitter & & & & & \\
\hline \multicolumn{8}{|l|}{ 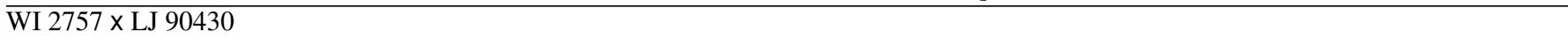 } \\
\hline$D$ & 85 & 34 & 119 & & & & \\
\hline$d$ & 6 & 28 & 34 & 30.28 & $>0.005$ & 26.1 & 3.6 \\
\hline$D f$ & 69 & 52 & 121 & & & & \\
\hline$d f$ & 22 & 10 & 32 & 3.08 & 0.40 & I & \\
\hline$F$ & 69 & 51 & 120 & & & & \\
\hline$f$ & 22 & 11 & 33 & 2.29 & 0.52 & I & \\
\hline$N s$ & 68 & 45 & 113 & & & & \\
\hline$n s$ & 23 & 17 & 40 & 0.83 & 0.99 & I & \\
\hline$P m-h$ & 71 & 38 & 109 & & & & \\
\hline$p m-h$ & 20 & 24 & 44 & 6.83 & 0.08 & I & \\
\hline Ss & 76 & 31 & 107 & & & & \\
\hline ss & 15 & 31 & 46 & 23.35 & $>0.005$ & 30.1 & 3.7 \\
\hline$T u$ & 86 & 33 & 119 & & & & \\
\hline$t u$ & 5 & 29 & 34 & 34.46 & $>0.005$ & 24.8 & 3.5 \\
\hline$U$ & 90 & 32 & 122 & & & & \\
\hline$u$ & 1 & 30 & 31 & 46.41 & $>0.005$ & 21.6 & 3.3 \\
\hline Total (9:7 segregation) & 91 & 62 & 153 & 0.65 & 0.45 & & \\
\hline \multicolumn{8}{|l|}{ NCG-198 x NCG-90 } \\
\hline$F$ & 66 & 47 & 113 & & & & \\
\hline$f$ & 22 & 13 & 35 & 0.95 & 0.81 & I & \\
\hline$G l$ & 65 & 47 & 112 & & & & \\
\hline$g l$ & 23 & 13 & 36 & 1.01 & 0.80 & I & \\
\hline Total (9:7 segregation) & 88 & 60 & 148 & 0.62 & 0.83 & & \\
\hline
\end{tabular}

${ }^{\mathrm{z}}$ Gene assortment is during the $\mathrm{F}_{2}$ generation where single genes should segregate in a 27 A_B_:21 A_bb:9 aaB_:7 aabb ratio when a 9:7 segregation ratio was being compared to $3: 1$ segregation ratio. Not all genes segregated independently (I) with $B t-2$. I = independent segregation.

$\mathrm{y}_{\mathrm{SE}}=$ standard error.

Table 6. Linkage relationship of fruit bitterness in PI 173889 (Bt) with several other genes.

\begin{tabular}{|c|c|c|c|c|c|c|c|}
\hline \multirow[b]{2}{*}{ PI $173889 x$ WI 2757} & \multicolumn{2}{|c|}{ Fruit bitterness } & \multirow[b]{2}{*}{ Total } & \multirow{2}{*}{$\begin{array}{l}\text { Chi- } \\
\text { square }\end{array}$} & \multirow{2}{*}{$\begin{array}{c}P \\
\text { value }\end{array}$} & \multirow{2}{*}{$\begin{array}{c}\text { Map } \\
\text { units }^{\mathrm{z}}\end{array}$} & \multirow[b]{2}{*}{$\mathrm{SE}^{\mathrm{y}}$} \\
\hline & Bitter & Nonbitter & & & & & \\
\hline$\overline{B i}$ & 76 & 30 & 106 & & & & \\
\hline$b i$ & 0 & 45 & 45 & 67.55 & $>0.005$ & 19.9 & 3.2 \\
\hline$D$ & 59 & 47 & 106 & & & & \\
\hline$d$ & 17 & 28 & 45 & 6.33 & 0.10 & I & \\
\hline$F$ & 55 & 61 & 116 & & & & \\
\hline$f$ & 21 & 14 & 35 & 1.88 & 0.61 & I & \\
\hline Ns & 61 & 62 & 123 & & & & \\
\hline$n s$ & 15 & 13 & 28 & 3.47 & 0.35 & I & \\
\hline Ss & 55 & 54 & 109 & & & & \\
\hline ss & 21 & 21 & 42 & 0.65 & 0.91 & I & \\
\hline$T u$ & 55 & 49 & 104 & & & & \\
\hline$t u$ & 21 & 26 & 47 & 4.00 & 0.27 & I & \\
\hline$U$ & 60 & 52 & 112 & & & & \\
\hline$u$ & 16 & 23 & 39 & 1.92 & 0.65 & I & \\
\hline Total(1:1) & 76 & 75 & 151 & 0.01 & 0.92 & & \\
\hline
\end{tabular}

${ }^{\mathrm{z}}$ Gene assortment is during the $\mathrm{F}_{2}$ generation where single genes should segregate in a $3 \mathrm{~A}_{-} \mathrm{B}_{-}: 3 \mathrm{~A} \_$bb : 1 aaB_: 1 aabb ratio when a 3:1 segregation ratio was being compared to 1:1 segregation ratio, as $B i$ was interacting with $B t$ to cause a 1:1 segregation of fruit bitterness. Not all genes segregated independently (I) with $B t$. I = independent segregation.

$\mathrm{y}_{\mathrm{SE}}=$ standard error.

therefore, may be located on the linkage group I described by Pierce and Wehner (1990). However, more linkage information is needed between $b i$ and other genes on this linkage group before $B t$ can be placed on linkage group I.

Weak linkages $(>25 \mathrm{cM})$ between several gene pairs in the present study $(B t-2-d e, d e-n s, d e-s s, d e-T u, d e-u, n s-F$, and $s s-F$ ) provide evidence that linkage group I and IV, as discussed by Pierce and Wehner (1990), may be linked (Fig. 1, Table 7). However, because these are weak linkages, more information needs to be obtained with respect to these gene combinations before we can be sure of this linkage association.

Other important linkages detected were $d f-d e$, and $g l-F$. 
Table 7. Linked gene pair combinations.

\begin{tabular}{|c|c|c|c|c|c|c|c|}
\hline Gene pair & Map units & $\mathrm{SE}^{\mathrm{Z}}$ & Family $^{y}$ & Gene pair & Map units & SE & Family $^{\mathrm{y}}$ \\
\hline$\overline{b i-B t^{x}}$ & 19.9 & 3.2 & 4 & $d e-T u^{x}$ & 42.6 & 9.7 & 7 \\
\hline$(B t-2)-d e^{\mathrm{x}}$ & 35.4 & 4.1 & 3 & $d e-u^{\mathrm{x}}$ & 48.4 & 6.4 & 7 \\
\hline$(B t-2)-D^{\mathrm{x}}$ & 26.1 & 3.6 & 1 & $d f-F^{\mathrm{v}}$ & 28.4 & 3.4 & 1 \\
\hline$(B t-2)-D^{\mathrm{x}}$ & 12.4 & 3.3 & 5 & $d f-F^{v}$ & 23.8 & 5.7 & 3 \\
\hline$(B t-2)-s s^{\mathrm{x}}$ & 30.1 & 3.7 & 1 & $d f-F^{\mathrm{w}}$ & 0.0 & 0.0 & 6 \\
\hline$(B t-2)-T u^{x}$ & 24.8 & 3.5 & 1 & $d f-d e^{\mathrm{w}}$ & 0.0 & 0.0 & 3 \\
\hline$(B t-2)-T u^{\mathrm{x}}$ & 22.4 & 3.5 & 5 & $F-g l^{\mathrm{x}}$ & 16.6 & 3.0 & 2 \\
\hline$(B t-2)-u^{\mathrm{x}}$ & 21.6 & 3.3 & 1 & $F-n s^{\mathrm{x}}$ & 44.4 & 6.6 & 7 \\
\hline$(B t-2)-u^{x}$ & 4.6 & 1.6 & 5 & $F-s s^{\mathrm{x}}$ & 31.5 & 5.2 & 1 \\
\hline$D-d e^{\mathrm{x}}$ & 0.0 & 0.0 & 7 & $F-s s^{x}$ & 45.3 & 6.6 & 7 \\
\hline$D-F^{\mathrm{x}}$ & 0.0 & 0.0 & 7 & $n s-s s^{v}$ & 22.1 & 3.1 & 1 \\
\hline$D-n s^{\mathrm{x}}$ & 33.3 & 3.8 & 4 & $n s-s s^{\mathrm{w}}$ & 3.8 & 1.3 & 3 \\
\hline$D-n s^{\mathrm{x}}$ & 0.0 & 0.0 & 7 & $n s-s s^{\mathrm{v}}$ & 11.3 & 2.2 & 4 \\
\hline$D-s s^{\mathrm{v}}$ & 25.9 & 3.4 & 1 & $n s-s s^{\mathrm{w}}$ & 4.3 & 1.7 & 7 \\
\hline$D-s s^{\mathrm{v}}$ & 23.6 & 3.2 & 4 & $n s-T u^{\mathrm{w}}$ & 39.8 & 4.1 & 4 \\
\hline$D-s s^{\mathrm{w}}$ & 0.0 & 0.0 & 7 & $n s-T u^{\mathrm{v}}$ & 19.8 & 5.4 & 7 \\
\hline$D-T u^{\mathrm{v}}$ & 14.8 & 2.5 & 1 & $n s-u^{v}$ & 49.7 & 6.2 & 7 \\
\hline$D-T u^{v}$ & 12.8 & 2.4 & 4 & $(p m-h)-T u^{v}$ & 35.7 & 3.9 & 1 \\
\hline$D-T u^{\mathrm{w}}$ & 31.0 & 4.1 & 5 & $(p m-h)-u^{v}$ & 31.1 & 3.6 & 1 \\
\hline$D-T u^{v}$ & 0.0 & 0.0 & 7 & $s s-T u^{v}$ & 20.0 & 2.9 & 1 \\
\hline$D-u^{\mathrm{v}}$ & 7.7 & 1.8 & 1 & $s s-T u^{v}$ & 24.5 & 3.3 & 4 \\
\hline$D-u^{\mathrm{v}}$ & 14.6 & 2.5 & 4 & $s s-T u^{v}$ & 11.6 & 4.1 & 7 \\
\hline$D-u^{\mathrm{v}}$ & 10.7 & 2.4 & 5 & $s s-u^{\mathrm{v}}$ & 20.4 & 2.9 & 1 \\
\hline$D-u^{\mathrm{v}}$ & 0.0 & 0.0 & 7 & $s s-u^{v}$ & 33.1 & 3.8 & 4 \\
\hline$d e-F^{\mathrm{v}}$ & 23.0 & 3.3 & 3 & $s s-u^{v}$ & 41.5 & 5.6 & 7 \\
\hline$d e-F^{v}$ & 35.4 & 5.1 & 7 & $T u-u^{v}$ & 7.7 & 1.8 & 1 \\
\hline$d e-n s^{\mathrm{x}}$ & 37.6 & 5.3 & 3 & $T u-u^{\mathrm{v}}$ & 6.2 & 1.7 & 4 \\
\hline$d e-n s^{\mathrm{x}}$ & 52.2 & 6.1 & 7 & $T u-u^{v}$ & 18.9 & 3.2 & 5 \\
\hline$d e-s s^{\mathrm{x}}$ & 35.8 & 5.3 & 3 & $T u-u^{v}$ & 15.8 & 4.8 & 7 \\
\hline$d e-s s^{\mathrm{x}}$ & 49.4 & 6.3 & 7 & & & & \\
\hline
\end{tabular}

${ }^{\mathrm{z}_{\mathrm{SE}}}=$ standard error.

'Family: 1 = WI 2757 x LJ 90430, 2 = NCG-198 x NCG90, 3 = NCG-198 x M21, 4 = PI 173889 x WI 2757, 5 = NCG-198 x 'Coolgreen', 6 = WI 2757 x 'Coolgreen', and 7 = NCG-199 x M21.

${ }^{x}$ New gene linkage relation.

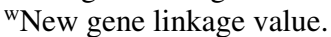

${ }^{\mathrm{v}}$ The value is close to that published.

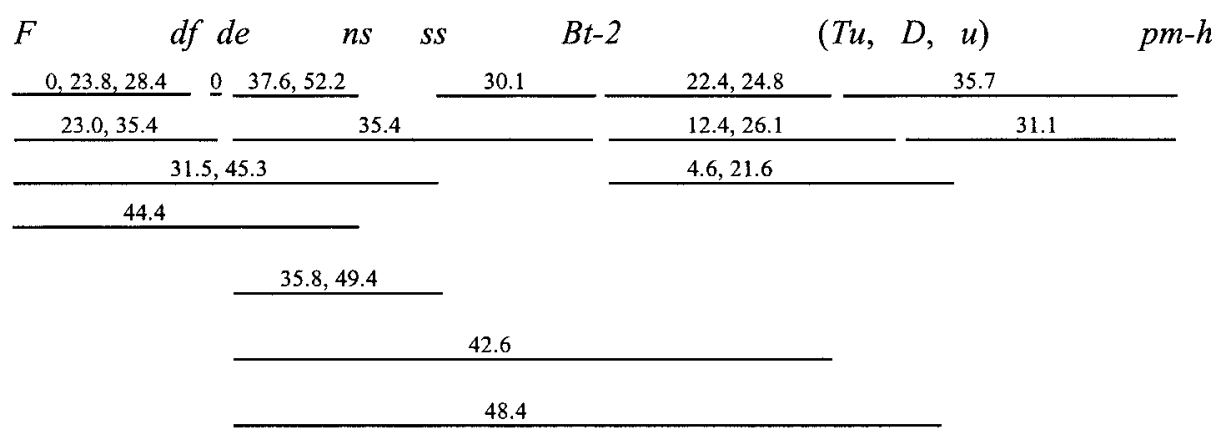

Fig. 1. Location of Bt-2 gene on linkage group IV and new linkages between linkage groups I and IV in cucumber based upon the six linkage groups that Pierce and Wehner (1990) assembled (two or three numbers on a single line indicate different estimates between the genes).

The genes $d f$ and $d e$ were tightly linked (Tables 2 and 7). Both $F$ and $g l$ are on the linkage group I described by Pierce and Wehner (1990), a linkage not detected previously. The following gene linkages were similar to previous reports $F$-de (Odland and Groff, 1963; Owens and Petersen, 1982), $F-d f, n s-s s, T u-u, T u-D$, $s s-D, s s-u, s s-T u$, and $u-D$ (Fanourakis and Simon, 1987;
Barham, W.S. 1953. The inheritance of a bitter principle in cucumbers. Proc. Amer. Soc. Hort. Sci. 62:441-442.

College of Agriculture and Life Sciences. 1995. The 1995 North Carolina agricultural chemical manual. N.C. State Univ, Raleigh.

College of Agriculture and Life Sciences. 1998. The 1998 North Carolina agricultural chemical manual. N.C. State Univ, Raleigh.

Cowen, N.M. and D.B. Helsel. 1983. Inheritance of two genes for spine color and linkages in a cucumber cross. J. Hered. 74:308-309.

Fanourakis, N.E. and P.W. Simon. 1987. Analysis of genetic linkage in the cucumber. J. Hered. 78:238-242. 
Foster, R., D. Egel, E. Maynard, R. Weinzierl, M. Babadoost, H. Taber, L. Jett, and B. Hutchison. 2000. Midwest vegetable production guide for commercial growers 2000. Univ. Ill. Ext. Bul. C1364.

Kennard, W., C. Poetter, A. Dijkhuizen, V. Meglic, J.E. Staub, and M.J. Havey. 1994. Linkage among RFLP, RAPD, isozyme, disease-resistance, and morphological markers in narrow and wide crosses of cucumber. Theor. Appl. Genet. 89:42-48.

Knerr, L.D. and J.E. Staub. 1992. Inheritance and linkage relationships of isozyme loci in cucumber (Cucumis sativus L.). Theor. Appl. Genet. 84:217-224.

Liu, J.S., T.C. Wehner, and S.B. Donaghy. 1997. SASGENE: A SAS computer program for genetic analysis of gene segregation and linkage. J. Hered. 88:253-254.

Meglic, V. and J.E. Staub. 1996. Inheritance and linkage relationships between allozyme and morphological loci in cucumber. Theor. Appl. Genet. 92:865-872.

Odland, M.L. and D.W. Groff. 1963. Linkage of vine type and geotrophic response with sex forms in cucumber Cucumis sativus L. Proc. Amer. Soc. Hort. Sci. 82:352-369.

Owens, K.W. and C.E. Peterson. 1982. Linkage of sex type, growth habit and fruit length in 2 cucumber inbred backcross populations. Cucurbit Genet. Coop. Rpt. 5:12.

Pierce, L.K. and T.C. Wehner. 1990. Review of genes and linkage groups in cucumber. HortScience 25:605-615.

Serquen, F.C., J. Bacher, and J.E. Staub. 1997. Mapping and QTL analysis of horticultural traits in a narrow cross of cucumber (Cucumis sativus L.) using random-amplified polymorphic DNA markers. Mol. Breeding 3:257-268.

Sinnott, E.W. and L.C. Dunn. 1939. Principles of genetics. $3^{\text {rd }}$ ed. McGraw-Hill, New York.

Staub, J.E. and V. Meglic. 1993. Molecular genetic markers and their legal relevance for cultigen discrimination: A case study in cucumber. HortTechnology 3:291-300.

Vakalounakis, D.J. 1992. Heart leaf, a recessive leaf shape marker in cucumber: Linkage with disease resistance and other traits. J. Hered. 83:217-221.

Walters, S.A. and T.C. Wehner. 1998. Independence of the $m j$ nematode resistance gene from 17 gene loci in cucumber. HortScience 33:1050 1052.

Wehner, T.C. 1993. Gene list update for cucumber. Cucurbit Genet. Coop. Rpt. 16:92-97.

Wehner, T.C. and J.E. Staub. 1997. Gene list for cucumber. Cucurbit Genet. Coop. Rpt. 20:66-88.

Weir, B.S. 1994. Genetic data analysis: Methods for discrete population data. Sinauer, Sunderland, Mass.

Whitaker, T.W. and G.N. Davis. 1962. Cucurbits. Leonard Hill, London. 